\title{
AB Ülkeleri ve Türkiye İşgücü Piyasasında Histeri Etkisi: RATCHET Modeli Analizi
}

\author{
İbrahim TOKATLIOĞLU \\ tokatli@gazi.edu.tr
}

\author{
Fahriye ÖZTÜRK \\ fahriye@gazi.edu.tr
}

Hakan Naim ARDOR

ardor@gazi.edu.tr

\section{Hysteresis Effect in Selected EU Countries and Turkey Labour Market: RATCHET Model Analysis}

\begin{abstract}
In this study, the effect of hysteresis in the labor market of selected $14 \mathrm{EU}$ member countries and Turkey for 1988-2011 period was analyzed. The present paper captures these effects by a simple extension of the hysteresis approach to the natural rate hypothesis of unemployment using a ratchet model with panel data. Due to the Ratchet model's dynamic structure, Arellano-Bond system GMM was used for estimates. As a result, it was concluded that selected 14 EU member countries' and Turkey's labor market has hysteresis. But, in these countries hysteresis effect (or Ratchet effects) is not so strong especially before the Global crises.

Keywords $\quad$ : Labor Market, Hysteresis Effect, Ratchet Model.

JEL Classification Codes : J01, C22, C23.

\section{Özet}

Çalışmada Türkiye'de dâhil seçilmiş 15 AB üyesi ülke işgücü piyasasında histeri etkisinin varlığı araştırılmıştır. Bu amaca yönelik olarak Ratchet modeli kullanılmıştır. AB üye ülkeler için yapılan çalışmada Arellano-Bond dinamik panel veri modeli ile tahmin yapılmıştır. Yapılan analizler sonucunda AB üyesi seçilmiş 15 ülkede Ratchet ve histeri etkisinin olduğu ancak zayıf bir seyir izlediği bulunmuştur. Doğal işsizlik oranı cari işsizlik oranını bir tepe noktasından başka bir tepe noktasına doğru ilerlerken takip etmekte ancak bu tepe noktasında kalıcılık göstermemekte ve cari işsizlik oranları düştüğünde doğal işsizlik oranı da düşmektedir.
\end{abstract}

Anahtar Sözcükler ： İşgücü Piyasası, Histeri Etkisi, Ratchet Modeli. 


\section{Acknowledgement}

Another version of this study with another title, model and content was also given in " 3 rd International Conference" which was held by Turkish Economic Association and Undersecretariat of Treasury on 1-3 November 2012, in Cesme, Izmir.

\section{Beyan}

$\mathrm{Bu}$ çalışma farklı bir model, içerik ve başlıkla Türkiye Ekonomi Kurumu ve Hazine Müsteşarlığı tarafından 1-3 Kasım 2012 tarihinde İzmir, Çeşme'de düzenlenen "3. Uluslararası Ekonomi Konferansı"nda sunulmuştur. 


\section{Giriş}

Son y1llarda gerek küresel boyutta gerekse de ülke ekonomilerinde yaşanan iktisadi bunalımlar ile tüm dünyada işsizlik oranları artmış ve işsizlik en çok tartışılan makro iktisadi olgulardan biri haline gelmiştir. İktisadi büyüme ile işsizlik arasındaki etkileşimin başlangıc1, A. W Phillips (1958) tarafından Birleşik Krallık ekonomisine yönelik, 1861- 1957 dönemine ait veriler kullanılarak yapılan çalışmaya dayanmaktadır. $\mathrm{Bu}$ çalışmada parasal ücretlerin artış oranı ile işsizlik oranı arasında ters yönlü bir ilişkinin varlığı istatistiksel açıdan ortaya konulmuştur. Phillips'in (1958) çalışmasındaki parasal ücretlerle işsizlik arasındaki ilişkiye yönelik bulgular iktisat yazınına Phillips Eğrisini (PE) kazandırmıştır. Daha sonra Samuelson ve Solow (1960) ABD ekonomisi için ve Lipsey (1960) İngiltere için yaptıkları çalışmalarla Phillips Eğrisinin varlığını doğrulamışlardır. PE çözümlemesinin en önemli nedeni enflasyon ile işsizlik arasındaki ilişkinin temel alınarak makro iktisadi politikalar için seçenek oluşturabilmesidir. Ancak 1970'li ve 1980'li yıllarda ABD ve İngiltere ekonomilerinde yaşanan iktisadi gelişmeler enflasyon ile işsizlik arasında istikrarlı bir ilişkinin olmadığı yönünde yeni argümanların ortaya çıkmasına neden olmuştur. Enflasyon ile işsizlik arasındaki ilişkinin uzun vadede devam etmediği ve PE’nin sürekli yukarıya doğru kaydığına yönelik yeni bulgular dile getirilmiştir. $\mathrm{Bu}$ bağlamda da işsizliği azaltmak veya aynı düzeyde tutmak için uygulanacak politikaların, sürekli daha yüksek bir enflasyon oranına katlanmak gerekliliğini ortaya çıkardığı gözlenmiştir.

PE'ne yönelik işaret edilen bu istikrarsızlık Keynesyen yaklaşımın eleştirilmesine yol açmıştır. Özellikle Parasalcılar ve daha sonra da Yeni Klasik İktisatçılar tarafından PE'ne yöneltilen eleştiriler enflasyon ile işsizlik oranı arasındaki ilişkinin doğasına yönelik alternatif yaklaşımların türemesine yol açmıştır. Parasalcılar, PE'ne yaklaşımlarını iki farklı yönden geliştirmişlerdir: Beklentilerin rolünün ve doğal işsizlik oranının çözümlemeye dâhil edilmesi. İlk olarak Friedman (1968) ve Phelps (1968) tarafından ortaya atılan "doğal işsizlik" oranı modern makroiktisadın kilit kavramlarından biri olmuştur. Doğal işsizlik kavramı yaklaşımı, Keynesyen İktisadın PE bağlamında ortaya koyduğu enflasyon ile işsizlik arasındaki ters yönlü ilişkinin geçerli olmadığını; kısa dönemde işsizlik azalsa bile uzun dönemde eski düzeyine döneceğini ve ekonomide bir doğal işsizlik oranının var olacağını savunmaktadır. Ancak ABD ve AB ülkelerinde yaşanan düşük enflasyon oranlarına karşın yüksek oranda işsizlik olgusuna ek olarak ücret enflasyonunun ortaya çıkması doğal işsizlik oranının varlığına olan inancı sarsmış ve doğal işsizlik oranına alternatif bir kavram Enflasyonu hızlandırmayan işsizlik oranı (NAIRU) ortaya atılmıştır. NAIRU kavramı 1975 yılında Franco Modigliani ve Lucas Papademos tarafından doğal işsizlik oranı hipotezini geliştirmek için kullanılmıştır (Lordoğlu ve Özkaplan, 2005: 428).

NAIRU terimi, $\pi_{t-1}$ beklenen enflasyon oranını göstermek için kullanılan denklemle ifade edilmektedir: 


$$
\pi_{t}=\pi_{t}^{e}+k \cdot\left(U_{t}-U^{*}\right)
$$

$\left(\pi_{t}\right) \mathrm{t}$ zamandaki enflasyon oranı, $\left(\pi_{t}^{e}\right) \mathrm{t}-1$ zamanında gerçekleşen enflasyonun t zamana yansıyan beklenen enflasyon oranını $\left(\pi_{t}^{e}=\pi_{t-1}\right),\left(\mathrm{U}_{\mathrm{t}}\right) \mathrm{t}$ zamanındaki işsizlik oranını ve (U*) NAIRU’yu (Stanley, 2002) ifade etmektedir.

Bir politika aracı olarak kullanılması önerilen NAIRU'nun sürekli olarak değişiyor olması kavrama yöneltilen eleştirilerden biridir. Çünkü kendisi sürekli değişen bir kavram hangi iktisat politikasının ne biçimde uygulanması gerektiğini de etkilemektedir. Birden fazla NAIRU değerinin olması, NAIRU'nun düzgün bir şekilde politika yapıcılar tarafindan tahmin edilmesi gerekliliği ve bunun da benzer biçimde politika önerme güçlüğü yaratması kavrama yöneltilen diğer bir eleştiri olarak görülmektedir (Lordoğlu ve Özkaplan, 2005: 433).

Ülke ekonomilerinde yaşanan şoklar NAIRU'nun değerini değiştirirken birden fazla NAIRU değerinin ortaya çıkması karşısında, diğer bir deyişle yaşanan şokların ardından işsizlik oranlarının öncekinden farklı bir noktada dengeye gelmesi başka bir alternatif terimin ortaya çıkmasına yol açmıştır: Histeri (Kesiklik)1. İktisadi şokların işsizlik oranları üzerinde kalıcı bir etkiye sahip olması ve işsizliğin denge değerini yükseltmesi işsizlik histerisi olarak anılmaktadır. Histeri terimi ilk kez Phelps (1972) tarafından kullanılmış ve kelime anlamı "arkasından gelen" biçiminde ifade edilmiştir. Histeri etkisi yaklaşımı doğal işsizlik oranının, kendiliğinden cari işsizlik oranını izleyeceğini öne sürmektedir.

Yukarıda vurgulandığı üzere, işsizlik olgusuna yönelik iki temel yaklaşım söz konusudur. Birincisi, ekonomideki geçici şokların ardından işsizlik oranının uzun dönem denge seviyesine geri döneceğini ifade eden, Friedman (1968) ve Phelps (1968) tarafindan ileri sürülen doğal işsizlik oranı yaklaşımıdır. İkincisi ise işgücü piyasasındaki katılıklar yüzünden geçici şokların ardından işsizlik üzerinde kalıcı bir etki ortaya çıkacağını ifade eden ve ilk olarak Phelps (1972) tarafindan ortaya atılmış, Blanchard ve Summers (1986, 1987), Layard vd. (1991) ve Barro (1988)'nun katkılarıyla biçimlenen "histeri” (kesiklik) etkisi yaklaşımıdır.

$\mathrm{Bu}$ çalışmada, gerek Türkiye işgücü piyasası gerekse de Avrupa Birliği (AB) üye ülkeler işgücü piyasasında histeri etkisi araştırılmıştır. Bu amaca yönelik olarak Ratchet Modeli ile Türkiye ve seçilmiş AB üyesi ülkelerin, 1988-2011 dönemini kapsayan yıllık verileri kullanılarak literatürde "Ratchet Etkisi" adı verilen etkinin ortaya çıkıp

I Histeri terimi Yunanca bir kelimedir. Fizik alanında "gecikmeli etki" anlamina gelmektedir. TDK (www.tdk.org.tr), iktisat terimi olarak "histeri" karşıllğında "kesiklik" ve "gecikme" terimlerini önermekte ve kesiklik, "Herhangi bir iktisadi değişkenin geçici bir şok sonrası başlangıç dengesine dönememesi durumu" biçiminde tanımlamaktadır. Çalışmada, yazında yaygın kullanımı olması nedeni ile "histeri" kelimesi kullanilacaktır. 
çıkmadığı araştırılmıştır. Çalışmada ayrıca $\mathrm{AB}$ üyesi ülkelerin işgücü piyasasında yaşanan histeri etkisinin kadın ve erkek işgücü açısından farklılık taşıyıp taşımadığı da incelenmiştir. Ratchet Modeli, daha önce, ABD, İngiltere ve diğer AB üyesi ülkeler için zaman serileri kullanılarak ele alınmış bir model olmasına rağmen, panel veri analizinde kullanılmamıştır. Ayrıca bu çalışma ile 2008 küresel krizi sonrası AB üyesi ülkelerde işsizlik histeri olgusunda yaşanan değişimleri de ele alma imkânı ortaya çıkacaktır.

\section{Literatür Özeti}

İşsizlik oranlarının bir şokun ardından eski düzeyine geri dönmediğini ifade eden işsizlik histerisine ilişkin çok sayıda çalışma mevcuttur. Çalışmada gerek Türkiye işgücü piyasasına yönelik gerekse $\mathrm{AB}$ ve diğer ülkeler işgücü piyasasında histeri etkisini araştıran çalışmalardan yalnızca bir kısmına yer verilmiştir. Aşağıda Tablo: 1'de Türkiye'de işsizlik histerisi üzerine yapılmış seçilmiş bazı çalışmalar yer almaktadır. Tablo: 1'de yer alan çalışmaların sonuçlarına bakıldığında kullanılan yöntem ne olursa olsun işsizlik histerisi varlığına ulaştıkları görülmektedir. Yalnızca Güloğlu ve İspir (2011), Türkiye'de 9 kesim ve 1988-2008 dönemi için, Carrion-i Silvestre çoklu yapısal kırılmayı dikkate alan panel birim kök testiyle yaptıkları çalışmada inşaat ve bayındırlık gibi bazı kesimler haricinde şokların işsizlik üzerinde uzun dönem ve kalıcı bir etki yaratmadığı bulgusuna ulaşmışlardır. Güloğlu ve İspir (2008: 213), yapısal kırılmayı dikkate almayan zaman serisi ve panel birim kök sınamalarının histeri önsavını, yapısal kırılmayı dikkate alan panel birim kök sınamasının ise doğal işsizlik oranı önsavını desteklediğine işaret etmektedirler.

Tablo: 1

Türkiye İşgücü Piyasasında Histeri Etkisi: Seçilmiş Bazı Çalışmalar

\begin{tabular}{|l|l|l|l|l|l|}
\hline YAZARLAR & YIL & MODEL & DÖNEM & KAPSAM & SONUÇ \\
\hline Küçükkale & 2001 & Kalman Filtre Tahmin Tekniği & $1950-1995$ & Türkiye & Var \\
\hline Pazarlığlu; Çevik & 2007 & RACHET MODEL & $1988-2004$ & Türkiye & Var \\
\hline Barşı; Çevik & 2008 & $\begin{array}{l}\text { Zivot-Andrews, Bai-Perron, } \\
\text { GPH, modifiye edilmiş } \\
\text { Log-Periodogram ve ARFIMA }\end{array}$ & $1923-2006$ & Türkiye & Var \\
\hline Yılanc1 & 2009 & $\begin{array}{l}\text { Perron, Zivot-Andrews (ZA), } \\
\text { Lumsdaine - Papell (LP), tek ve iki } \\
\text { kırılmalı LM birim kök testleri }\end{array}$ & $1923-2007$ & Türkiye & Var \\
\hline Tunalı & 2010 & Eşbütünleşme analizi & $2002-Q 1-2008-Q 4$ & Türkiye & Var \\
\hline Güloğlu; İspir & 2011 & $\begin{array}{l}\text { Carrion-İ Silvestre Panel } \\
\text { Birim Kök Sınaması }\end{array}$ & $1988-2008$ & Türkiye & $\begin{array}{l}\text { Bazı Sektörler } \\
\text { Haricinde Yok }\end{array}$ \\
\hline Koçyiğit; Bayat; Tüfekçi & 2011 & STAR modelleri & $1923-2010$ & & VAR \\
\hline Onur & 2011 & $\begin{array}{l}\text { UBK'ya uygun } \\
\text { otoregresif bir model }\end{array}$ & $\begin{array}{l}\text { Enflasyon } \\
\text { Hedeflemesi } \\
\text { Histeriye Yol } \\
\text { Aç1yor }\end{array}$ \\
\hline
\end{tabular}

Kaynak: Tarafimızdan oluşturulmuştur.

Avrupa ve diğer ülkelerle ilgili işsizlik histerisine yönelik seçilmiş bazı çalışmalar Tablo: 2'de verilmiştir. Tablo: 2 incelendiğinde işsizlik histerisini destekleyen ve desteklemeyen ya da kısmen destekleyen çalışmalar olduğu görülmektedir. Genellikle 
birim kök sınama yöntemi kullanılan çalışmaların sonuçlarının işsizlik histerisine işaret ettiği dikkat çekmektedir.

Tablo: 2

Seçilmiş Bazı Ülkeler İşgücü Piyasasında Histeri Etkisi: Seçilmiş Bazı Çalışmalar

\begin{tabular}{|c|c|c|c|c|c|}
\hline YAZARLAR & YIL & MODEL & DÖNEM & KAPSAM & SONUÇ \\
\hline BLANCHARD; SUMMERS & 1986 & Birim Kök Sınama & 1953-1984 & FRANSA, ALMANYA, INGILLTERE & VAR \\
\hline JONES; MANNING & 1992 & Birim Kök Sınama & 1967-1987 & İNGİLTERE-10 BÖLGE & VAR \\
\hline CRATO, Rothman & 1996 & ARFIMA & 1960-1994 & $\begin{array}{l}\text { KANADA, ALMANYA, JAPONYA, } \\
\text { İNGILTERE, ABD }\end{array}$ & $\begin{array}{l}\text { K.,A. ve ABD } \\
\text { için 1960-1974 } \\
\text { VAR; } \\
\text { 1973-1994: } \\
\text { YOK } \\
\text { J. ve İn. VAR }\end{array}$ \\
\hline KOUSTAS; VELOCE & 1996 & ARFIMA & 1942-1992 & KANADA & $\begin{array}{l}\text { VAR (ERKEK } \\
\text { İ̧ÇiLER } \\
\text { IÇiN DAHA } \\
\text { BELIRGIN) }\end{array}$ \\
\hline GIL, ALANA & 2001 & ARFIMA & 1968-1998 & AVRUPA ÜLK., ABD & $\begin{array}{l}\text { AV. ÜLK. } \\
\text { VAR; } \\
\text { ABD'DE YOK }\end{array}$ \\
\hline SMYTH, EASAW & 2001 & RATCHET & 1948-1998 & $\mathrm{ABD}$ & VAR \\
\hline GIL-ALANA & 2002 & ARFIMA & 1966-2002 & KANADA & VAR \\
\hline LEDESMA & 2002 & Birim Kök Sinama & 1985-1999 & $\mathrm{ABD}$ (51 eyalet) $\mathrm{AB} 12$ & $\begin{array}{l}\text { AB12 } \\
\text { HiSTERİ } \\
\text { ETKİİ } \\
\text { ABD: DOĞAL } \\
\text { İŞSizLiK }\end{array}$ \\
\hline CHANG VE DİĞ. & 2005 & Birim Kök Sinama & 1961-1999 & AB 10 & $\begin{array}{l}\text { BELÇIKA VE } \\
\text { HOLLANDA } \\
\text { DISSINDA } \\
\text { VAR } \\
\end{array}$ \\
\hline CUESTAS, GIL-ALANA & 2011 & YAPISAL KIRILMA & $1997-2010$ & \begin{tabular}{|l|} 
MERKEZ VE \\
DOĞU AVRUPA ÜLKELERİ
\end{tabular} & VAR \\
\hline
\end{tabular}

Kaynak: Tarafimızdan oluşturulmuştur.

\section{Model}

Çalışmada, Smyth ve Easaw (2001) ile Pazarlıoğlu ve Çevik (2007)'nin de çalışmalarında kullandıkları Ratchet Modeli ile AB seçilmiş üye ülkeler ve Türkiye'de işsizliğin histeri etkisi taşıyıp taşımadığı araştırılacaktır. Çalışmada kullanılan modelin tanıtımında geniş ölçüde Smyth ve Easaw (2001)'in çalışmasından yararlanılmıştır. Smyth ve Easaw (2001) Ratchet Modelini 1948-1998 yılları arasında ABD işgücü piyasası için kullanmış iken Pazarlığlu ve Çevik (2007a) 1988-2004 yılları arasında Türkiye işgücü piyasası ve Pazarlıoğlu ve Çevik (2007b) 1938-2005 yılları arası yine Türkiye işgücü piyasası için kullanmışlardır.

Yazında Ratchet Etkisi, bağımsız değişkendeki bir değişmeye bağımlı değişkenin vereceği tepkinin sabit olmadığı, tersine değişimin yönüne göre değişebileceği biçimindeki yaklaşım olarak tanımlanmaktadır. Örneğin bağımsız değişken artarken artan bağımlı değişken, bağımsız değişken azaldığında azalmıyor olabilir. Bu duruma literatürde Ratchet Etkisi denilmektedir. Kısa dönemde işsizlik oranlarında artış veya azalma 
yönündeki bir değişme olabilir; ancak uzun dönemde işsizlik oranlarındaki değişmenin basamak biçiminde artışlar olarak gerçekleşmesi durumunda Ratchet etkisinin varlığından söz edilebilir (Pazarlıŏlu ve Çevik, 2007: 45). Ratchet, değişkenin arttıktan sonra eski seviyesine dönmesini engelleyen durum olarak da değerlendirilebilir ${ }^{2}$. Ratchet etkisinin varlığı işgücü piyasasında histeri etkisinin varlığını da gösterebilmektedir. Histeri, NAIRU'nun gerçekleşen işsizlik oranı patikasını otomatik olarak takip etmesi anlamına da gelmektedir. Böylece işsizlik rakamlarındaki basamaklı artış Ratchet etkisi ile birlikte histeri etkisini gösterebilmektedir. Klasik Ratchet Modelinde, bağımsız değişken bir tepe noktasından diğer bir tepe noktasına giderken, yani artarken, bağımsız değişken belirli bir eğimle bu artışı takip etmektedir. Ancak bağımsız değişken bir dip noktasından bir tepe noktasına giderken veya bir tepe noktasından bir dip noktasına giderken bağımlı değişken farklı bir eğimle muhtemelen daha düşük bir eğimle hareket etmektedir (Smyth ve Easaw, 2001: 360). Buna göre, eğer histeri etkisi mevcut ise işsizlik bir tepe noktasından diğer bir tepe noktasına doğru yol aldığında bunun etkisinin (eğiminin) NAIRU üzerindeki etkisi farklı iken, tepe noktasından dip noktasına doğru bir değişimin NAIRU üzerindeki etkisi (eğiminin) daha düşük olacaktır. Cari işsizlik ile NAIRU arasında Ratchet etkisinin varlığ gösterilebilirse, işsizlik oranlarında histeri etkisinin varlığı da gösterilmiş olacaktır. Bu yüzden modelin tanıtımına genişletilmiş Philips Eğrisi denklemi ile başlamak gerekmektedir.

En temel doğal işsizlik oranı denklemi aşağıdaki gibi yazılabilir.

$$
U_{t}-U_{t}^{*}=-\alpha\left(\pi_{t}-\pi_{t-1}\right)+\varepsilon_{t}
$$

Burada;

$\mathrm{U}_{\mathrm{t}}$, işsizlik oranını

$\mathrm{U}_{\mathrm{t}}{ }^{*}$, doğal işsizlik oranını (daha sonra NAIRU denilecektir)

$\Pi_{\mathrm{t}}$, enflasyon oranını

$\Pi_{\mathrm{t}-1}$, enflasyon beklentisini temsil etmesi için geçmiş dönem enflasyon oranını

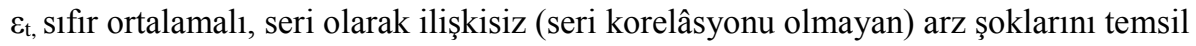
etmektedir.

$\mathrm{Bu}$ yaklaşım doğal işsizlik oranı ile gerçekleşen işsizlik arasındaki farkın beklenti hatasının bir fonksiyonu olduğunu göstermektedir. Geleneksel olarak NAIRU histeri etkisini içerecek şekilde aşağıdaki gibi ifade edilmektedir.

2 İngilizce bir kelime olan Ratchet’in Türkçe karşıllı̆̆ kilit mandalı olarak düşünülebilir. Bir çarkın geri dönmesini engelleyen ve çarkın dişlileri arasına giren kilit olarak ele alınabilir. 
$U_{t}^{*}=\mu U_{t-1}$

$\mu=1$ olduğunda tam histeri olduğu ifade edilir ve böylece Ratchet Modelinin histeri etkisini aşağıdaki gibi yazabiliriz:

$U_{t}^{*}=\beta_{1} U_{t-1}+\beta_{2} U_{t-1}^{\text {tepe }}$

$\mathrm{U}_{\mathrm{t}-1}{ }^{\text {tepe }}$, işsizliğgin bir önceki tepe noktasını göstermektedir.

Burada $\beta_{1}+\beta_{2}, \mathrm{U}_{\mathrm{t}-1}$ bir tepe noktasından diğer tepe noktasına giderken NAIRU'yu ne düzeyde peşinden sürüklediğini gösteren histeri etkisini vermektedir. $\beta_{1}$ ise işsizlikteki azalmanın ve/veya işsizlik oranlarının dipten tepeye doğru artarken NAIRU'nun da yüksek takip etkisine sahip olduğunu, yani işsizlik oranlarında histeri etkisinin olduğunu göstermektedir.

$\beta_{1}+\beta_{2} \cong 1$ olması durumunda tam yada saf histeri etkisi mevcuttur yani tek bir doğal işsizlik oranı bulunmamaktadır.

(1) ve (3) denklemlerini beraber yazıp çözersek;

$U_{t}=\beta_{1} U_{t-1}+\beta_{2} U_{t-1}^{\text {tepe }}-\alpha\left(\pi_{t}-\pi_{t-1}\right)+\varepsilon_{t}$

Denklemine ulaşırız. Ulaştı̆̆ımız bu denklem yardımı ile histeri etkisini ölçmek mümkündür. (4) numaralı denklem işsizlik kalıcılığının sadece geçmiş dönem işsizlik oranının ne olduğuna değil aynı zamanda bir önceki tepe noktasına da bağlı olduğunu göstermektedir. Aşağıdaki bölümde söz konusu denklemi kullanarak yaptı̆̆ımız tahminler ve bunlara ilişkin sonuçlar tartışlacaktır.

\section{Veri ve Tahmin}

Yukarıda ulaşılan histeri etkisini gösteren (4) nolu denklem, seçilmiş bazı AB üyesi ülkeler için panel veri seti ile tahmin edilmeye çalışılacaktır.

Çalışmada AB ülke verileri için işsizlik rakamları İLO'nun Key Indicator of the Labour Market (KILM) veri setinden enflasyon rakamları ise IMF'nin IFS veri setinden alınmıştır. Veriler 1988-2011 yılları arasını kapsamaktadır. Dengeli panel veri seti oluşturabilmek için veri olmasına rağmen bazı ülkeler (Almanya, Polonya vb gibi) ile bazı yıllar (1980-1987 arası) model dışında bırakılmıştır.

Modelde yer alan ülkeler aşağıdaki Tablo: 3'de gösterilmiştir. 
Tablo: 3

Modelde Yer Alan Ülkeler

\begin{tabular}{|l|l|l|}
\hline Avusturya & Belçika & Danimarka \\
\hline Finlandiya & Fransa & Yunanistan \\
\hline İrlanda & İtalya & Lüksemburg \\
\hline Hollanda & Portekiz & İspanya \\
\hline İsveç & Türkiye & İngiltere \\
\hline
\end{tabular}

Şekil: 1

Modelde Yer Alan Ülkelere Ait İşsizlik ve Enflasyon Verileri Serpme Diyagramı
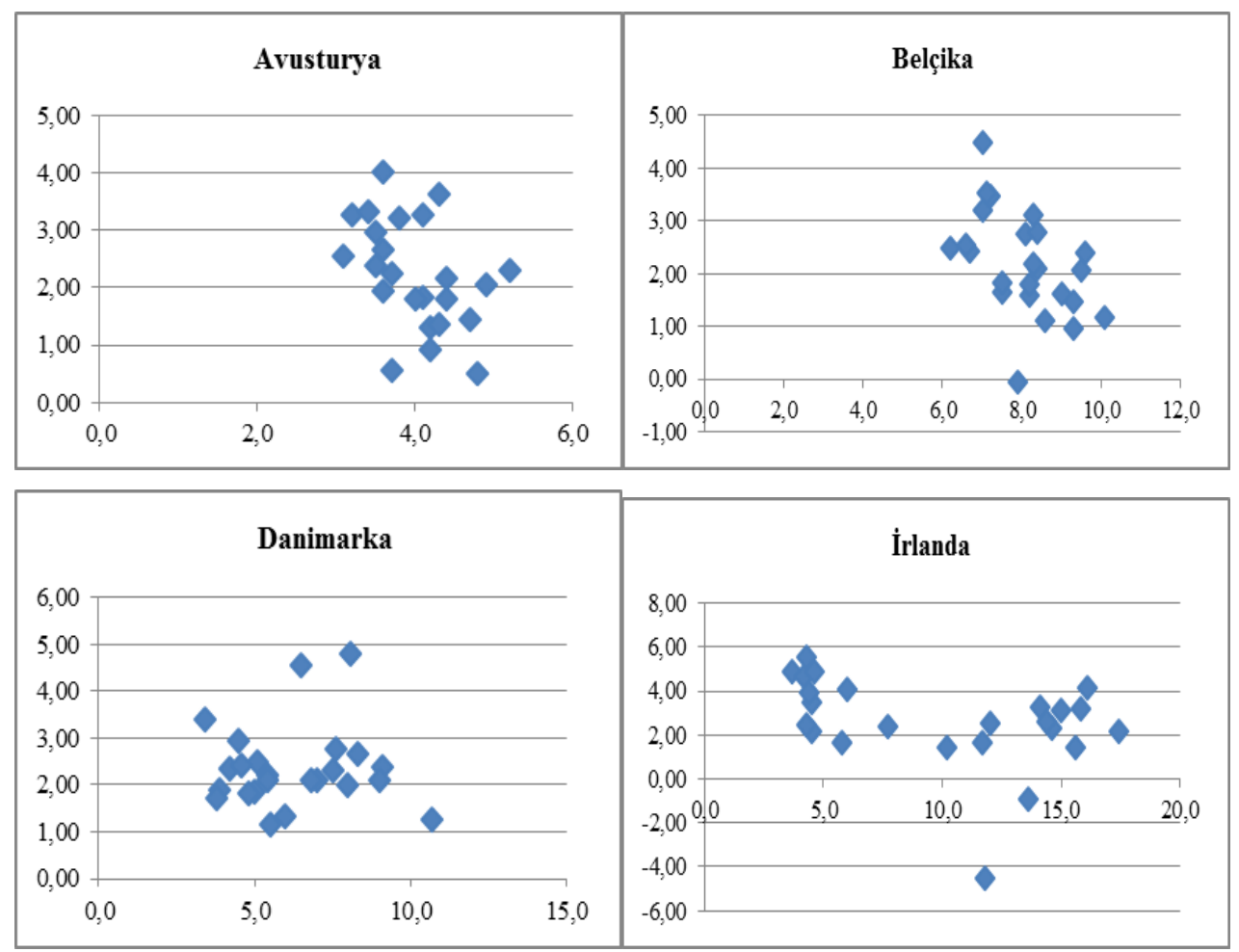
İbrahim TOKATLIOĞLU \& Fahriye ÖZTÜRK \& Hakan Naim ARDOR
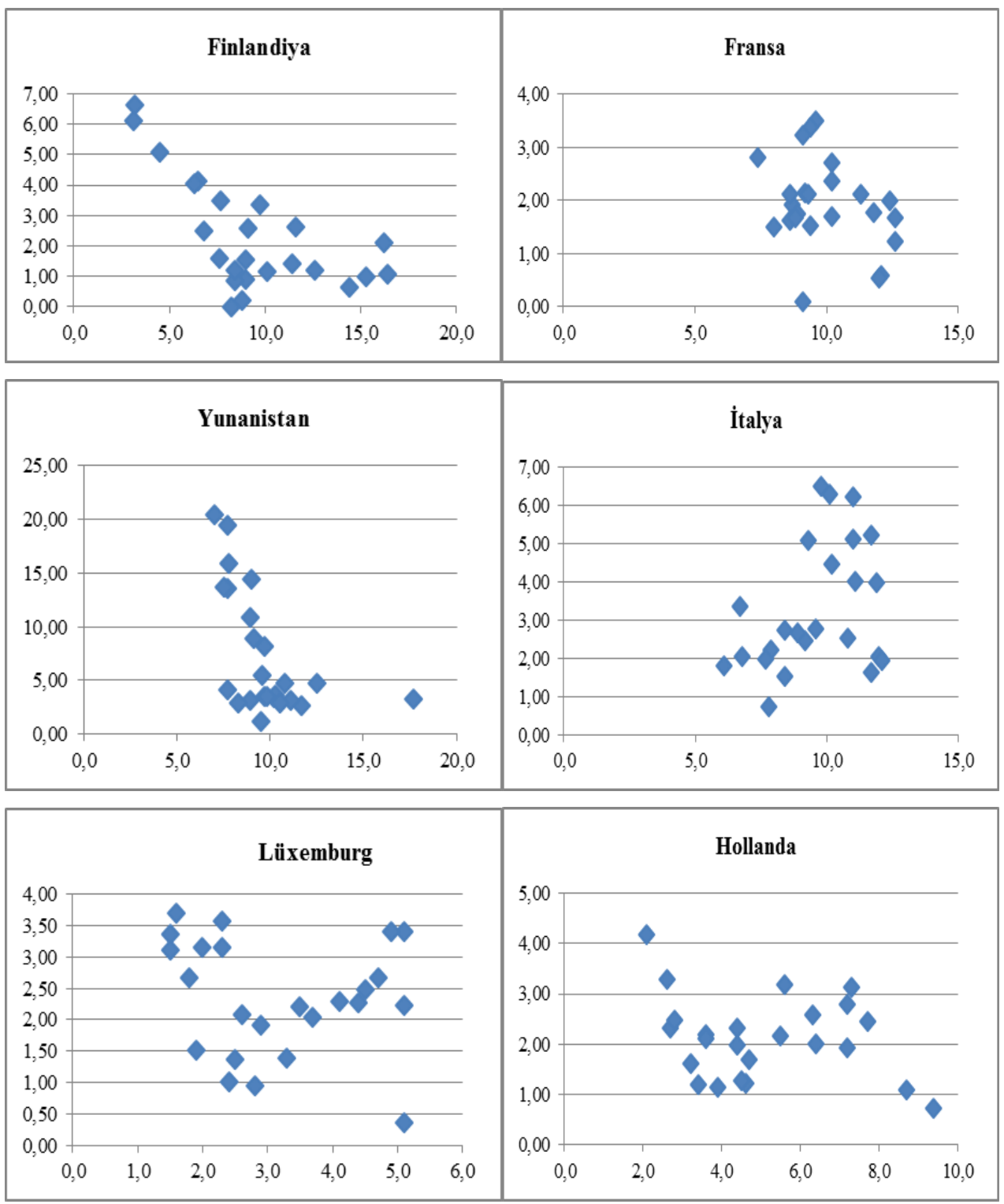

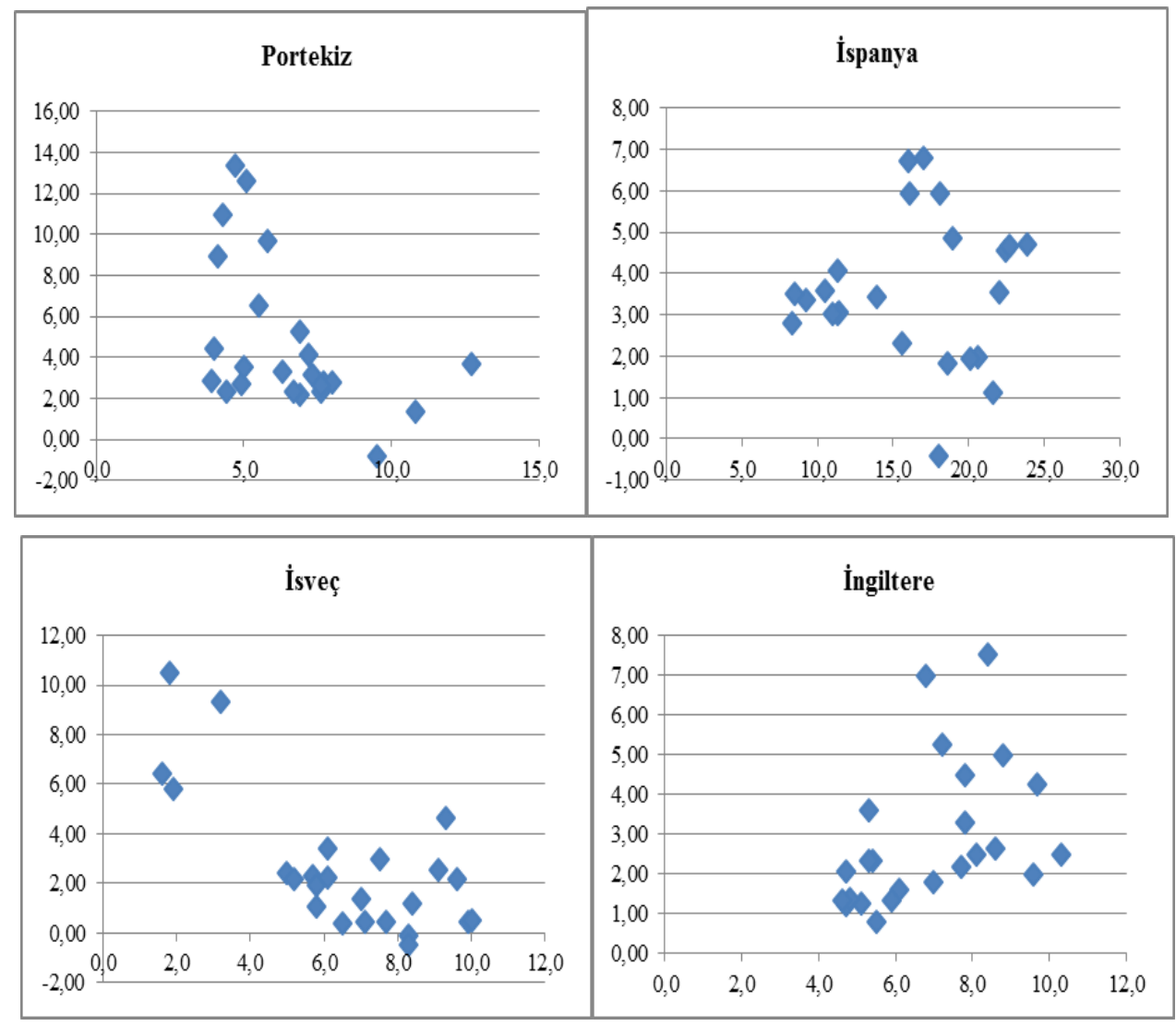


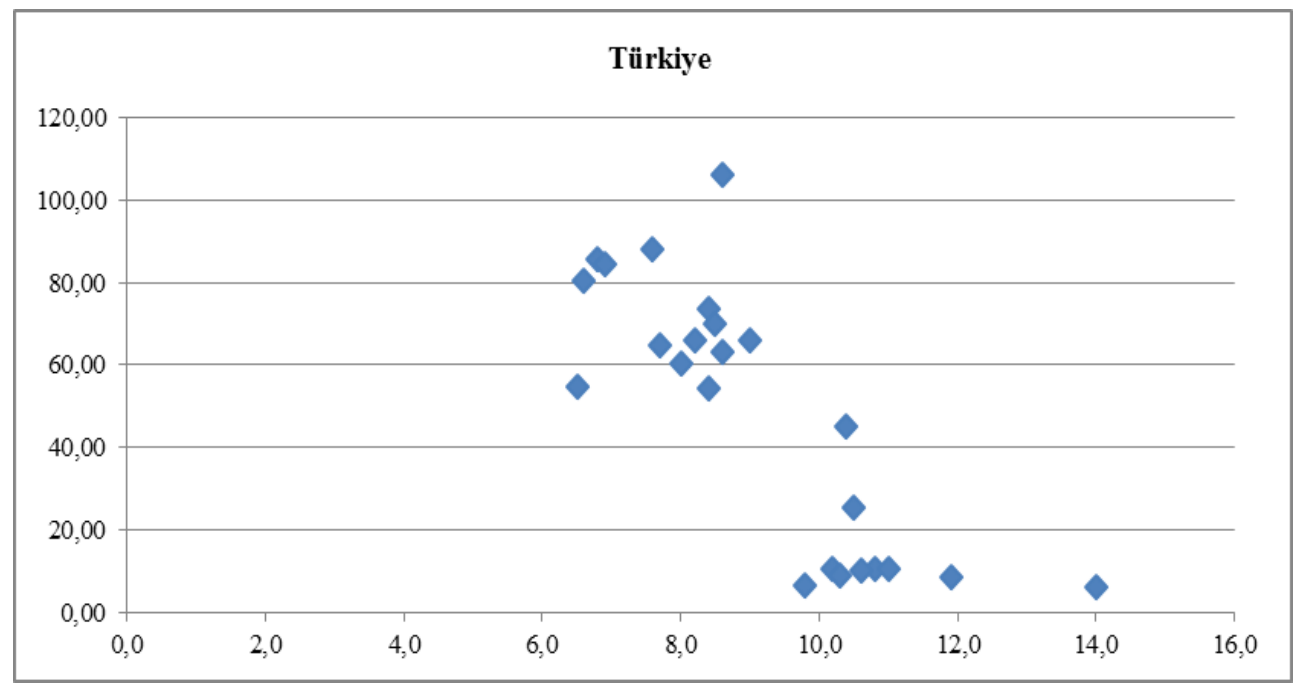

Serpme diyagramlardan da görülebileceği gibi İtalya, Lüksemburg ve İngiltere dışındaki ülkelerde enflasyon ile işsizlik arasındaki ilişki negatif eğimli gibi görünmektedir. Bunun yanında Belçika, İrlanda, Hollanda ve Portekiz dışındaki ülkelerde işsizlik oranları tepe noktaları yıllar içinde basamak şeklinde bir yükselme seyri göstermektedir. $\mathrm{Bu}$ durumda da Ratchet Modelinin bu ülkelerden oluşan panel veri seti için kullanılabilir bir model olduğu sonucu ortaya çıkmaktadır.

1988-2011 yılları arasında ülkelerin ortalama işsizlik oranları dikkate alındığında Lüksemburg'un çok düşük, İspanya'nın ise çok yüksek değerlere sahip olduğu görülmektedir. 
Şekil: 2

Ülkelere Göre Ortalama İşsizlik Oranları

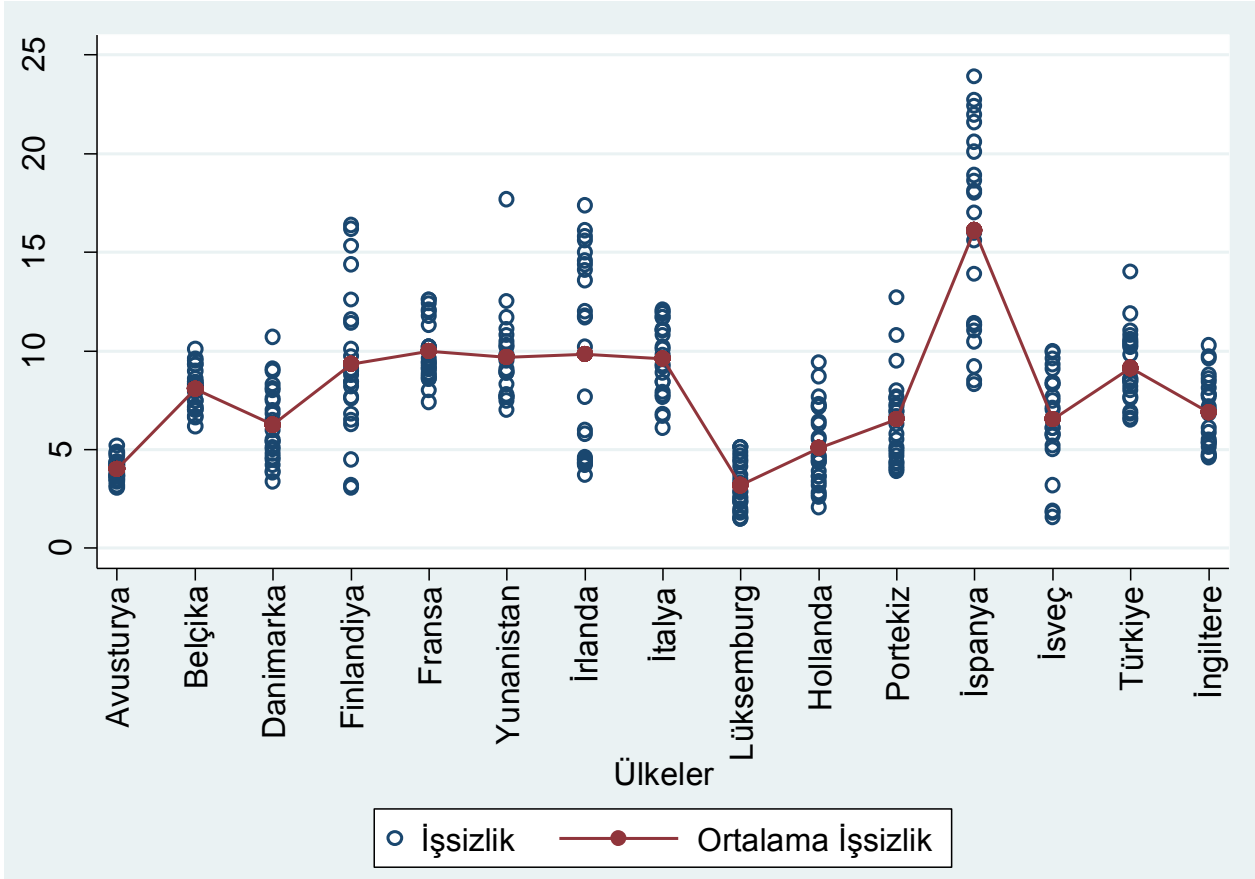

Türkiye'de de benzer bir dağılım söz konusudur. Şekil: 3 'den de görülebileceği gibi Türkiye işgücü piyasasında işsizlik oranlarının tepe noktaları yıllar içerisinde basamak şeklinde yükselmektedir.

Modelde kullanılan işsizlik oranı ve enflasyon verilerinin durağan olup olmadıkları Levin, Lin ve Chu (2002)'nun çalışmalarında belirlediği yöntemle test edilmiştir. Levin-Lin-Chu (LLC) testinde boş hipotez, tüm panel verilerinin birim kök taşıdığ1 şeklinde belirlenmişken alternatif hipotez verilerin durağan olduğu yönündedir. Yapılan analiz sonucunda hem enflasyon hem de işsizlik oranları verilerinin birim kök taşımadığ1 yani durağan oldukları sonucuna ulaşılmıştır. İşsizlik oranı tepe noktaları verisi üretilmiş bir veri olduğundan ve değişim oranları sınırlı olduğundan birim kök testine tabi tutulmamıştır. 
Şekil: 3

Türkiye'de İşsizlik Oranları ve Tepe Noktaları (1988-2011)

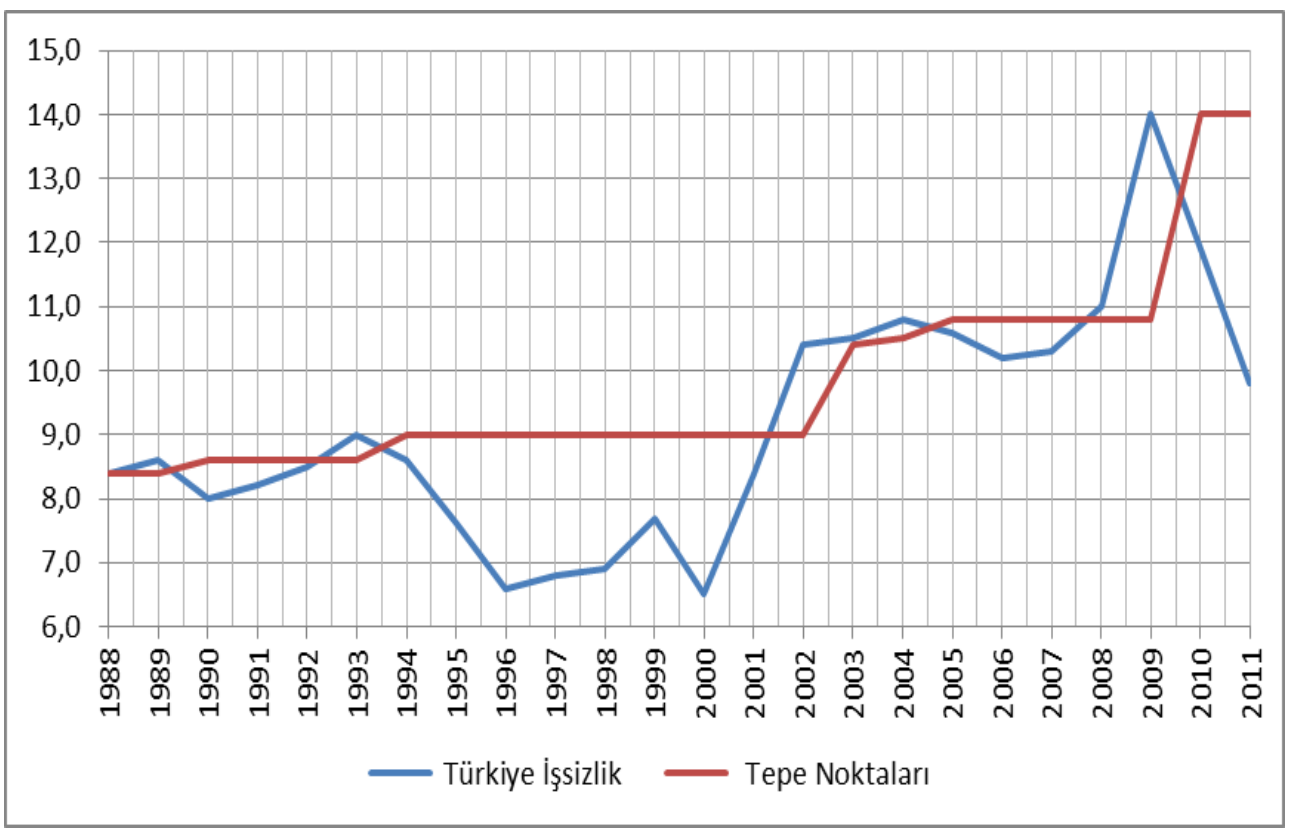

Tablo: 4

İşsizlik ve Enflasyon Verilerine Ait Birim Kök Test Sonuçları

\begin{tabular}{|c|c|c|c|c|}
\hline Değişken & t-istatistiği & Düzeltilmiş t-istatistiği & Olasılık Değeri & Sonuç \\
\hline İşsizlik oranı & $-7,902$ & $-2,947$ & 0,0016 & Durağan \\
\hline Enflasyon & $-7,968$ & $-4,180$ & 0,0000 & Durağan \\
\hline
\end{tabular}

Tahmin denkleminde kullanılan değişkenler durağan olduğundan Ratchet modeli ilk önce rastsal etkiler modeli ile tahmin edilmiştir. Tahmin sonuçları aşağıdaki tabloda verilmiştir.

Tablo: 5

Rastsal Etki Modeli ile Ratchet Model Tahmin Sonuçları

\begin{tabular}{|c|c|c|c|}
\hline Değişken & Katsayı & z istatistiği & Olasıllk Değeri \\
\hline $\mathrm{U}_{\mathrm{t}-1}$ & 0,9571 & 41,80 & 0,000 \\
\hline $\mathrm{U}^{\text {tepe }} \mathrm{t}-1$ & $-0,0045$ & $-0,25$ & 0,805 \\
\hline$\pi_{\mathrm{t}}-\pi_{\mathrm{t}-1}$ & $-0,0594$ & $-3,11$ & 0,002 \\
\hline Sabit & 0,4310 & 2,52 & 0,012 \\
\hline \multicolumn{2}{|c|}{} & \multicolumn{2}{|c|}{ Wald $\mathrm{Chi}^{2}=3212,55$} \\
\hline
\end{tabular}

Tablodan da görülebileceği gibi $\beta_{1}+\beta_{2}=0,9526$ değerini almaktadır. $\mathrm{Bu}$ da 
uzun dönemde doğal işsizlik oranının hareketli olduğu anlamına gelmektedir. Ayrıca $\beta_{1}$ 'in büyüklüğü dipten tepe noktasına yönelik hareketin doğal işsizlik oranını peşinden sürüklediğini de göstermektedir. Bu model çerçevesinde $\beta_{2}{ }^{\prime}$ in $\mathrm{z}$ istatistiğinin düşük olduğu görülmektedir. Ayrıca bu regresyon yöntemi, ülkelerin farklılıklarını göz ardı etmekte ve her bir ülkenin işgücü piyasasının kendine has özelliklerini yansıtan değişkenin modelde yer almasını engellemektedir. Bunu test edebilmek için Breusch ve Pagan'ın rastsal etkiler modeli için Lagrange Çarpanı (LM) testi yapılmıştır. LM testinin boş hipotezi ülke verileri arasında varyansın sıfır olduğu şeklinde belirlenmiştir. Bunun anlamı ülkelerin arasında anlamlı bir farklılığın olmadığıdır. Yapılan test sonucunda $\mathrm{Chi}^{2}$ değeri sıfır olarak bulunmuştur. Bunun anlamı modelde rastsal etkiler modelinin kullanılmasının uygun olmadığıdır. Bu yüzden model sabit etkiler modeli ile yeniden tahmin edilmiştir. Tahmin sonuçları aşağıda verilmektedir.

Tablo: 6

Sabit Etki Modeli ile Ratchet Model Tahmin Sonuçları

\begin{tabular}{|c|c|c|c|}
\hline Değişken & Katsayı & t istatistiği & Prob. Değeri \\
\hline $\mathrm{U}_{\mathrm{t}-1}$ & 0,9096 & 35,11 & 0,000 \\
\hline $\mathrm{U}^{\mathrm{tepe}}{ }_{\mathrm{t}-1}$ & $-0,1903$ & $-4,41$ & 0,000 \\
\hline$\pi_{\mathrm{t}}-\pi_{\mathrm{t}-1}$ & $-0,0545$ & $-2,89$ & 0,004 \\
\hline Sabit & 2,89 & 5,89 & 0,000 \\
\hline \multicolumn{2}{|c|}{} & \multicolumn{2}{|c|}{ F-test $=414$} \\
\hline
\end{tabular}

Sabit etki modeli, rastsal etkiler modelinden daha başarılı bir modeldir. Sabit etkiler modeli ülkelerin farklılıklarına izin veren bir tahminleme yöntemidir. Buna göre her bir ülkenin işgücü piyasası reflekslerinin birbirinden farklı olduğu, ancak ele alınan zaman içerisinde bu farklılıkların değişmediği varsayılmaktadır. Tahmin edilen parametrelerin t istatistikleri katsayıların istatistiki olarak anlamlı olduklarını göstermektedir. Tablodan da görülebileceği gibi $\beta_{1}+\beta_{2}=0,7193$ değerini almaktadır. Ratchet Etkisi rastsal etkiler modelinde elde edilenden daha düşük çıkmıştır. Ancak yine de Ratchet etkisi yüksektir. Benzer şekilde $\beta 1$ katsayısı da yüksek çıkmıştır. Yani gerçekleşen işsizlik oranları dipten tepe noktasına doğru yükseldiğinde doğal işsizlik oranını (ya da NAIRU'yu da) da peşinden sürüklemektedir. Rastsal etkiler veya sabit etkiler modellerinin hangisinin daha uygun olduğuna dair Hausman testi yapılmış ve $\mathrm{Chi}^{2}$ değeri 32,41 olarak bulunmuştur. Bunun anlamı sabit etkiler modelinin tahminleme için daha uygun olduğudur.

Baltagi (2005)'ye göre, panel veri analizinde uzun dönem içeren serilerde (2030 yıl gibi) yatay kesit bağımlılı̆̆ (cross-section dependence) önemli bir sorun olabilmektedir. Panel veri analizinde yatay kesit bağımlılı̆g birkaç farklı testle incelenmektedir. Eğer panel veri setinde zaman boyutu, yatay kesit boyutundan daha büyük ise genellikle Breusch-Pagan Lagrange Çarpanı (LM) bağımlılık testi kullanılmaktadır. Ancak bu test grup ortalaması sıfır iken ülke ortalamasının sıfırdan farklı olması durumunda sapmalı sonuçlar verebilmektedir. Bu yüzden çalışmada yatay kesit bağımlılığının olup olmadığı Breusch-Pagan (1980) yatay kesit bağımlılığı Lagrange çarpanı testi (B-P/LM testi), Peseran (2004) testi, Friedman (1937) testi ve Frees (1995 ve 
2004) testi ile gösterilmiştir. Test sonuçları aşağıdaki tablo da verilmektedir.

Tablo: 7

Yatay Kesit Bağımlılığı Test Sonuçları

\begin{tabular}{|c|c|c|}
\hline Test & İstatistik & Olasılık Değeri \\
\hline Breusch-Pagan LM Testi & 421,395 & 0,000 \\
\hline Pesaran CD Testi & 18,155 & 0,000 \\
\hline Friedman Testi & 135,07 & 0,000 \\
\hline & & Q Dağılımı Kritik Değerleri \\
Frees Testi & 1,887 & 0,10 için 0,1124 \\
& & 0,05 için 0,1470 \\
& & 0,01 i̧çin 0,2129 \\
\hline
\end{tabular}

B-P/LM testi için boş hipotez ülkeler arasında artıklar ilişkili değildir şeklindedir. Yukarıdaki tablodan da görülebileceği gibi boş hipotez çıkan sonuçlar doğrultusunda reddedilmektedir. Yani ülke hata terimleri arasında belirli bir ilişki mevcut görünmektedir. Bunun yanında modelde bağımlı değişken, aynı zamanda bağımsız değişken olarak kullanıldığından aslında model dinamik bir yapıdadır. Panel veri analizlerinde dinamik bir yapı söz konusu iken eğer havuzlanmış EKK (veya rastsal ekiler modeli) yöntemi kullanılırsa parametre tahminleri yukarı yönlü, sabit etkiler modeli ile tahminleme yapılırsa, parametre tahminleri aşağı yönlü sapmalı olmaktadır. Bu durum literatürde Nickell Sapması (Nickell Bias) olarak adlandırılmaktadır. Bu sapmalı tahminleri düzeltebilmek için literatürde kullanılan en yaygın yöntem Arellano and Bond (1991)'un önerdikleri dinamik panel veri GMM tahminlemesidir. Dinamik yapıdaki panel veri analizlerinde gecikmeli bağımlı değişkenin hata terimleri ile olan korelasyonunu giderebilmek ve sapmasız tahminler yapabilmek için gecikmeli bağımlı değişkenin yerine genellikle araç değişken kullanılmaktadır. Anderson ve Hsiao (1981), dinamik modellerde birinci farkların kullanılarak birim etkinin dışlanabileceğini ileri sürmüştür (Baltagi 2005). Çünkü birim etkiyi dişlayan alternatif bir dönüşüm olan birinci fark (first difference, FD) dönüşümünde açıklayıcı değişkenle hata terimi arasındaki korelasyonu ele almak daha kolaydır (Ar1 ve Özcan, 2011: 108).

Ancak birinci fark alındığında da hala gecikmeli bağımlı değişkenin etkisi söz konusu olacaktır. Birinci farklar alındığında yapılan tahminlemede de sonuçlar tutarlı ancak etkin olmayacaktır. Arellano ve Bond (1991) bu sorunun olası tüm araç değişkenlerin modele dâhil edilmemesinden kaynaklandığını belirtmiştir. Arellano ve Bond (1991), tüm geçerli gecikmeli değişkenlerin dinamik panel veri modellerinde araç değişken olarak kullanılmasını önererek genelleştirilmiş momentler yöntemini (GMM, GeneralizedMethod ofMoments) geliştirmiştir (Ar1 ve Özcan, 2011: 109).

Çalışmada Arellano-Bond (1991)'un geliştirilmesi ile elde edilen ArellanoBover (1995)'un önerdikleri sistem GMM tahminlemesi kullanılarak elde edilen sonuçlar aşağıdaki tabloda verilmiştir. Denkleme 2008 krizinin etkilerini de yansıtması açısından 2008, 2009 ve 2010 yılları için kukla değişken de eklenmiştir. 
Tablo: 8

Arellano-Bond Dinamik Panel Veri Tahmin Sonuçları

\begin{tabular}{|c|c|c|c|c|}
\hline Değişken & Katsayı & Standart Hata & z-istatistiği & Olasılık Değeri \\
\hline $\mathrm{U}_{\mathrm{t}-1}$ & 0,9294541 & 0,0196734 & 47,24 & 0,000 \\
\hline $\mathrm{U}_{\mathrm{t}-1}^{\mathrm{tepe}}$ & $-0,2898616$ & 0,0343021 & $-8,45$ & 0,000 \\
\hline$\pi_{\mathrm{t}}-\pi_{\mathrm{t}-1}$ & $-0,0541776$ & 0,0139542 & $-3,88$ & 0,000 \\
\hline Kukla Değişken & 1,29285 & 0,1443124 & 8,96 & 0,000 \\
\hline \multicolumn{5}{|c|}{ Wald testi=2239,27olasılık değeri:0,000 } \\
\hline \multicolumn{5}{|c|}{$\begin{array}{l}\text { AR(1) için Arellano-Bond testi } z=-5,65 \text { olasılık değeri }=0,000 \\
\text { AR(2) için Arellano-Bond testi } z=0,95 \text { olasılık değeri }=0,344\end{array}$} \\
\hline \multicolumn{5}{|c|}{ GMM için Sargan testiChi ${ }^{2}=313,74$ olasılık değeri $=0,295$} \\
\hline \multicolumn{5}{|c|}{ Araç Değişkenler için Sargan testi $\mathrm{Chi}^{2}=13,75$} \\
\hline
\end{tabular}

Tahmin edilen katsayıların yorumlanmasına geçmeden önce dinamik GMM tahminlemesine yönelik testlerin açıklanması yararlı olacaktır. Bu amaçla sistem GMM tahmincilerinin tutarlılığı test edilmiştir. Wald testi bağımsız değişkenlerin birlikte bağımlı değişkeni açıklamada anlamlı olduğunu göstermektedir. AR(1) için Arellano-Bond (AB) testi $\mathrm{z}$ değeri beklentilerimiz doğrultusunda yüksek çıkmıştır. Yine beklentilerimiz doğrultusunda $\mathrm{AR}(2)$ için $\mathrm{AB}$ testi olasılık değeri boş hipotezi reddedemeyeceğimizi göstermektedir. $\mathrm{AB}$ testi için belirlenen boş hipotez otokorelasyonun olmadığı yönündedir. $\mathrm{AB}$ testlerine göre $\mathrm{AR}(2)$ sürecinde otokorelasyon olmadığ 1 için Arellano-Bond dinamik GMM modelinin kullanılması uygundur.

Sargan testinin boş hipotezi araç değişkenlerin grup olarak dişsal olduğu yönündedir. Sargan testi olasılık değeri boş hipotezi reddetmek için uygun donelere sahip olmadı̆̆ımızı göstermektedir. Dolayısıyla araç değişkenlerin dışsal olduğu ve kullanımının doğru olduğu sonucuna ulaşılmıştır.

Tahmin edilen katsayılar istatistikî olarak \%1 önemlilik düzeyinde hepsi anlamlı çıkmıştır. Modelden elde edilen Ratchet Etkisinin boyutu ise oldukça düşmüştür. $\beta_{1}+\beta_{2}=0,6395$ olarak bulunmuştur. $\mathrm{Bu}$ durum, cari işsizlik oranı dipten tepe noktasına doğru hareket ettiğinde doğal işsizlik oranının bunu takip eğiliminin yüksek olduğu, ancak cari işsizlik oranı tepe noktasından bir başka tepe noktasına hareket ettiğinde doğal işsizlik oranının bu hareketi izleme konusunda yavaş davrandığ 1 şeklinde yorumlanabilir. Cari işsizlik oranı bir tepe noktasından bir diğer tepe noktasına geçtiğinde doğal işsizlik oranının burada kalma eğiliminin düşük olduğunu göstermektedir. Yani $\mathrm{AB}$ üyesi seçilmiş ülkelerle yaptığımız analizde Ratchet Etkisinin zayıf olduğunu söylemek mümkündür. $\mathrm{Bu}$ ülkelerde doğal işsizlik oranı cari işsizlik oranını takip etmekte, bu yüzden ülkelerde tek bir doğal işsizlik oranı söz konusu olmamakta ancak cari işsizlik oranlarının azaldığ durumlarda doğal işsizlik oranı da azalmaktadır.

Çalışmada, $\mathrm{AB}$ ülkeleri işgücü piyasasında kadın ve erkek nüfusun işsizliğinde histeri etkisinin varlığı da ayrı ayrı ele alınmıştır. Bu amaçla yine aynı model çerçevesinde 
kadın $\left(\mathrm{U}_{\mathrm{F}}\right)$ ve erkek $\left(\mathrm{U}_{\mathrm{M}}\right)$ işsizlik verileri kullanılarak Ratchet ve histeri etkisi tahmin edilmiştir ${ }^{3}$. Kadın ve erkek nüfusa ait Ratchet ve histeri etkileri sadece Arellano-Bond sistem-GMM modeli ile tahmin edilmiştir. Kadın ve erkek işsizlik histeri etkisine bakmadan önce kadın ve erkek nüfusa ait işsizlik oranı verilerinin durağan olup olmadıkları Levin-Lin-Chu (LLC) testi ile sınanmıştır. Sınama sonuçları aşağıdaki tabloda verilmektedir.

Tablo: 9

Kadın ve Erkek İşsizlik Oranlarına Ait Birim Kök Test Sonuçları

\begin{tabular}{|c|c|c|c|c|}
\hline Değişken & t-istatistiği & Düzeltilmiş t-istatistiği & Olasılık Değeri & Sonuç \\
\hline $\mathrm{U}_{\mathrm{F}}$ & $-6,7338$ & $-2,4260$ & 0,0076 & Durağan \\
\hline $\mathrm{U}_{\mathrm{M}}$ & $-8,471$ & $-2,9408$ & 0,0016 & Durağan \\
\hline
\end{tabular}

Levin-Lin-Chu (LLC) birim kök testi sonuçlarına göre gerek kadın işsizlik oranı gerekse de erkek işsizlik oranı verileri durağan görünmektedir. Kadın işsizliğine ait tahmin sonuçları aşağıdaki tabloda gösterilmektedir.

\section{Tablo: 10}

\section{Kadın İşgücü İçin Arellano-Bond Dinamik Panel Veri Tahmin Sonuçları}

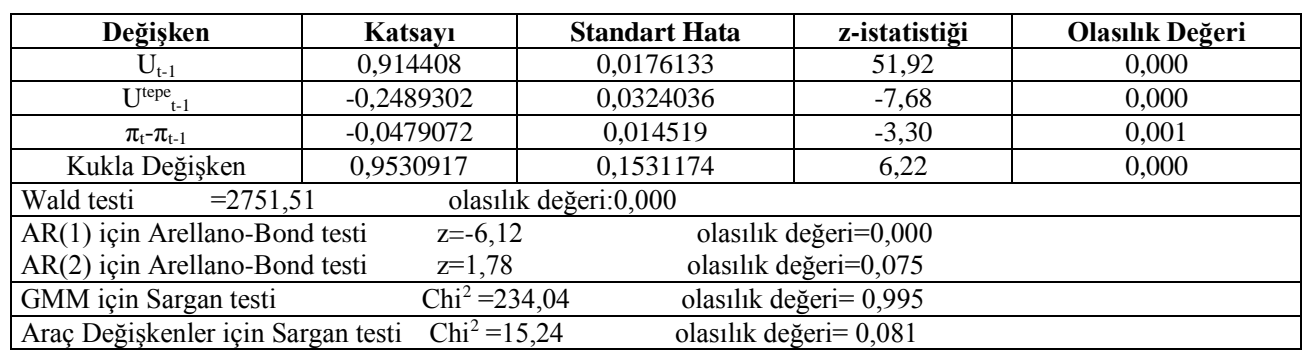

$\mathrm{AB}$ üyesi seçilmiş 15 ülke işgücü piyasasında kadın işsizliği histerisine yönelik yapılan Arellano-Bond dinamik panel veri analizi sonucunda elde edilen Wald testi, bağımsız değiş̧kenlerin bir bütün halinde bağımlı değişkeni açıklamada anlamlı olduğunu göstermektedir. Tahminlemede Arellano-Bond yönteminin kullanılmasının gerekliliğini de $A R(1)$ sürecinin otokorelasyon taşıdığı ama $A R(2)$ sürecinin ise taşımadığını gösteren Arellano-Bond testi sonuçları göstermektedir. Sargan testi sonuçlarının da modelde kullanılan araç değişkenlerinin dışsal olduklarını göstermektedir. Tahmin edilen katsayılar istatistikî olarak \%1 önemlilik düzeyinde hepsi anlamlı çıkmıştır. Modelden elde edilen Ratchet Etkisinin boyutu ise $\beta_{1}+\beta_{2}=0,6654$ düzeyindedir. Kadın işsizliğinde Ratchet ve histeri etkisi bir miktar artmış gözükmektedir. Tüm işgücü piyasasında bu düzey 0,6395

3 Kadın işsizlik oranı tüm işgücü içindeki kadın işsizlik oranı değil kadın işgücü içindeki kadın işsiz oranını göstermektedir. Benzer şekilde erkek nüfusu işsizlik oranı, tüm işgücü içerisindeki erkek işsizlerin oranının değil sadece erkek işgücü nüfusu içerisindeki erkek işsiz nüfusunun oranını vermektedir. Dolayısıla erkek işsizlik oranı ile kadın işsizlik oranları toplamı ülkedeki toplam işsizlik oranını göstermemektedir. 
olarak bulunmuştu. Yani kadın işsizlik histerisi genel işsizlik histerisinden daha yüksek görünmektedir. Kadın işsizliğinde bir tepe noktasından diğer bir tepe noktasına doğru hareket olduğunda kadın doğal işsizlik oranı da bunu takip etmektedir. Kadın işsizliğindeki kalıcılık genel işsizlikteki kalıcılıktan daha büyük olmaktadır. Kadın işgücünde işsizlik bir dip noktasından bir tepe noktasına yöneldiğinde doğal işsizlik oranı da cari düzeyleri yakından ve 1srarlı bir şekilde takip etmektedir. Ancak doğal işsizlik oranının tepe noktalarında süreklilik kazanmamakta ve cari işsizlik oranları azaldığında doğal işsizlik oranları da azalmaktadır.

AB üyesi 15 seçilmiş ülke işgücü piyasalarında erkek işsizliği için ArellanoBond dinamik panel analizi sonuçları da aşağıdaki tabloda verilmektedir.

Tablo: 11

Erkek İşgücü İçin Arellano-Bond Dinamik Panel Veri Tahmin Sonuçları

\begin{tabular}{|c|c|c|c|c|}
\hline Değişken & Katsayı & Standart Hata & z-istatistiği & Olasılık Değeri \\
\hline $\mathrm{U}_{\mathrm{t}-1}$ & 0,9206709 & 0,0223346 & 41,22 & 0,000 \\
\hline $\mathrm{U}_{\mathrm{t}-1}^{\mathrm{tepe}}$ & $-0,2516038$ & 0,0297699 & $-8,45$ & 0,000 \\
\hline$\pi_{\mathrm{t}}-\pi_{\mathrm{t}-1}$ & $-0,0592878$ & 0,0155172 & $-3,82$ & 0,000 \\
\hline Kukla Değişken & 1,549025 & 0,1589918 & 9,74 & 0,000 \\
\hline \multicolumn{5}{|c|}{ Wald testi $\quad=1741,05 \quad$ olasıllk değeri:0,000 } \\
\hline \multirow{2}{*}{\multicolumn{2}{|c|}{$\begin{array}{l}\text { AR(1) için Arellano-Bond testi } \\
\text { AR(2) için Arellano-Bond testi }\end{array}$}} & \multirow{2}{*}{\multicolumn{2}{|c|}{$\begin{array}{l}\text { olasıllk değeri }=0,000 \\
\text { olasılık değeri }=0,624\end{array}$}} & \\
\hline & & & & \\
\hline \multirow{2}{*}{\multicolumn{2}{|c|}{ GMM için Sargan testi }} & \multicolumn{2}{|c|}{ olasılık değeri $=0,432$} & \\
\hline & & \multicolumn{2}{|c|}{ olasılık değeri $=0,111$} & \\
\hline
\end{tabular}

AB üyesi seçilmiş 15 ülke işgücü piyasasında erkek işsizliği histerisine yönelik yapılan Arellano-Bond dinamik panel veri analizi sonucunda elde edilen Wald testi, bağımsız değişkenlerin bir bütün halinde bağımlı değişkeni açıklamada anlamlı olduğunu göstermektedir. Tahminlemede Arellano-Bond yönteminin kullanılmasının gerekliliğini de $\mathrm{AR}(1)$ sürecinin otokorelasyon taşıdığı ama $\mathrm{AR}(2)$ sürecinin ise taşımadığını gösteren Arellano-Bond testi sonuçları göstermektedir. Sargan testi sonuçlarının da modelde kullanılan araç değişkenlerinin dışsal olduklarını göstermektedir. Tahmin edilen katsayılar istatistikî olarak \%1 önemlilik düzeyinde hepsi anlamlı çıkmıştır. Modelden elde edilen Ratchet Etkisinin boyutu ise $\beta_{1}+\beta_{2}=0,6690$ düzeyindedir. Erkek nüfus işsizliğindeki Ratchet ve Histeri etkisi hem genel nüfus hem de kadın nüfusu işsizlik histerisinden yüksek çıkmıştır.

Çalışmada 2008 Küresel Ekonomik Krizin işsizlik histerisi ve Ratchet etkisi üzerindeki etkisini gözlemleyebilmek için hem tüm nüfus hem de kadın ve erkek nüfusu için yukarıdaki tahminler 1988-2007 yılları arası için tekrar yapılmıştır. Çalışmada bu tahminlerden elde edilen Ratchet Etkisi tablolaştırılacak, tahmin sonuçları ayrıca irdelenmeyecektir. 
Tablo: 12

1988-2007 ve 1988-2011 Dönemlerine Ait Ratchet Etkisi Karşılaştırması

\begin{tabular}{|c|c|c|c|c|c|c|}
\hline & \multicolumn{2}{|c|}{ Tüm Nüfus } & \multicolumn{2}{c|}{ Kadın } & \multicolumn{2}{c|}{ Erkek } \\
\cline { 2 - 7 } & $\mathbf{1 9 8 8 - 2 0 1 1}$ & $\mathbf{1 9 8 8 - 2 0 0 7}$ & $\mathbf{1 9 8 8 - 2 0 1 1}$ & $\mathbf{1 9 8 8 - 2 0 0 7}$ & $\mathbf{1 9 8 8 - 2 0 1 1}$ & $\mathbf{1 9 8 8 - 2 0 0 7}$ \\
\hline $\begin{array}{c}\boldsymbol{\beta}_{\mathbf{1}}+\boldsymbol{\beta}_{\mathbf{2}} \\
\text { Ratchet Etkisi }\end{array}$ & 0,6395 & 0,6232 & 0,6654 & 0,6417 & 0,6690 & 0,6372 \\
\hline $\boldsymbol{\beta}_{\mathbf{1}}$ & 0,9294 & 0,9361 & 0,9144 & 0,9342 & 0,9206 & 0,9075 \\
\hline
\end{tabular}

Yukarıdaki tablodan da görülebileceği gibi 2008 krizi öncesi tüm nüfus gruplarında Ratchet ve histeri etkisi daha düşük görünmektedir. 2008 krizi sonrası erkek nüfus işsizlik oranlarında daha belirgin olmak üzere histeri etkisinde bir artma olmuştur. Bununla birlikte cari işsizlik oranının dipten tepe noktasına doğru arttığı durumda doğal işsizlik oranının bunu takip etme kabiliyeti erkek nüfusta artarken kadın nüfusta azalış göstermektedir. Yani kadın nüfusa ait doğal işsizlik oranı erkek doğal işsizlik oranına nazaran daha yavaş bir artış göstermektedir. Bu durum işgücü piyasasında kadın nüfusun daha hızlı istihdam edildiği şeklinde yorumlanabilir.

\section{Sonuç ve Değerlendirme}

Çalı̧̧mada $\mathrm{AB}$ üyesi seçilmiş 14 ülke ve Türkiye işgücü piyasalarında işsizlik histerisinin olup olmadığı Ratchet Modeli çerçevesinde ele alınmıştır. Çıkan sonuçlara göre nüfusun tümü dikkate alındığında histeri etkisinin düşük çıktığı gözlenmiştir. Bunun yanında kadın ve erkek nüfusa ait işsizlik histerisi ayrı ayrı ele alındığında, zayıf görünse de genel nüfusa ait histeri etkisinden daha yüksek bir histeri etkisi olduğu görünmektedir.

Çalışmada ayrıca yukarı doğru Ratchet etkisi olduğu sonucuna ulaşılmıştır. İşsizlik oranları dipten tepe noktasına doğru çıkarken doğal işsizlik oranını da peşinden sürüklemektedir. Dolayısıyla doğal işsizlik oranı veya NAIRU hareketlidir. Avrupa Birliği’nde işsizliğin gecikmeli değerinin tahmin edilen katsayısı oldukça yüksek çıkmıştır. Bunun anlamı işsizlik dipten tepe noktasına doğru yükselirken, NAIRU ya da doğal işsizlik oranını da peşinden sürüklemektedir. $A B$ işgücü piyasalarında Ratchet etkisi ile birlikte histeri etkisinin var olduğu ancak zayıf bir seyir izlediği söylenebilir. Yine yapılan analizlerde $\mathrm{AB}$ işgücü piyasalarında kadın ve erkek işgücüne ait işsizlik rakamları dikkate alındığında histeri etkisinin $\mathrm{AB}$ toplam işgücüne ait histeri etkisinden yüksek olduğu gözlemlenmektedir.

2008 krizi sonrasında işgücü piyasasında histeri etkisinde bir yükselme yaşanmıştır. İşsizlik histerisinden en çok erkek nüfus etkilenmiştir. Kadın nüfusa ait doğal işsizlik oranı, erkek nüfusa ait doğal işsizlik oranından daha yavaş yükselmiştir. Bu durum kriz sonrası dönemde erkek nüfusun istihdam edilme kabiliyetinin kadın nüfusa göre daha düşük olduğu şeklinde yorumlanabilmektedir. Kadın istihdamının hizmetler sektöründe daha yaygın olduğu dikkate alındığında bu durum anlamlı görünmektedir. Erkek nüfusun işsizliğinin kalıcılığının kriz sonrası dönemde kadın işsizliği kalıcılığına göre artmış olması istihdamın cinsiyet dağılımının erkek istihdamının aleyhine gelişmesine neden olmuştur. 


\section{Kaynakça}

Anderson, T.W. \& C. Hsiao (1981), "Estimation of Dynamic Models with Error Components", Journal of the American Statistical Association, 76 (375), 98-606.

Arellano, M. \& S. Bond. (1991), "Some tests of specification for panel data: Monte Carlo evidence and an application to employment equations", Review of EconomicStudies, 58: 277-297.

Arı, A. \& B. Özcan (2011), "İşçi Gelirleri ve Ekonomik Büyüme İlişkisi: Dinamik Panel Veri Analizi”, Erciyes Üniversitesi İktisadi Ve İdari Bilimler Fakültesi Dergisi, Sayı: 38, Haziran-Aralık 2011, 101-117.

Baltagi, B.H. (2005), Econometric Analysis of Panel Data, 3rd ed. New York: Wiley.

Barışık, S. \& E.İ. Çevik (2007), “Türkiye’de İşsizlikte Histeri Etkisinin Parçalı Durağanlık Testi İle Analizi”, 8. Ulusal Ekonometri ve İstatistik Sempozyumu, 24-25 Mayıs 2007, Malatya.

Barışı, S. \& E.İ. Çevik (2008), “İşsizlikte Histeri Etkisi: Uzun Hafıza Modelleri”, Kamu-İŞ Dergisi, C:9(4), 1-36.

Barro, R. (1988), “The Natural Rate Theory Reconsidered: The Persistence of Unemployment”, American Economic Review, 78(2): 32-37.

Baum, C.F. (2001), "Residual diagnostics for cross-section time-series regression models", StataJournal, 1: 101-104.

Blanchard, O. ve Summers, L. (1987) "Hysteresis in Unemployment" European Economic Review, vol: 31(1) pp: 288-95.

Blanchard, O. \& J. Wolfers (2000), "The Role of Shocks and Institutions in the Rise of European Unemployment: The Aggregate Evidence”, Economic Journal, Vol.: 110(462), 1-33.

Blanchard, O.J. \& L.H. Summers (1986), "Hysteresis and the European Unemployment Problem", Journal of Econometrics, Vol:74, 119-147.

Breusch, T. \& A. Pagan (1980), "The Lagrange multiplier test and its application to model specification in econometrics", Review of EconomicStudies, 47: 239-253.

Bulutay, T. (1995), Employment, Unemployment and Wages in Turkey, Ankara, International Labour Office.

Camarero, M. \& C. Tamarit (2004), "Hysteresis vs. Natural Rate Of Unemployment: New Evidendence for OECD Countires", Economics Letters, Vol:84, 413-417.

Casado, J.M. \& J. Trivez (2004), “Asymmetry, Persistence And Non-Linearity of Spanish Unemployment Rates", General Economics And Teaching, 0406001, 1-32.

Crato, N. \& P. Rothman (1996), "Measuring Hysteresis in Unemployment Rates With Long Memory Models", Workpaper, <http://pascal.iseg.utl.pt/ ncrato/papers/urlm01.pdf〉, 24.11.2013.

Cross, Rod (1990), "Unemployment, Hysteresis and the Natural Rate Hypothesis", Reviewed: J. Luis Guasch, Journal of Economic Literature, Vol. 28, No.1, 107-108.

Cross, Rod B. (1987), "Hysteresis and Instability in the Natural Rate of Unemployment", The Scandinavian Journal of Economics, 89, No.1, 71-89. 
Cross, Rod B. \& M. Grinfeld \& H. Lamba (2009), "Hysteresis in Economic Systems”, special issue on Hysteresis in Natural and Engineered Systems, IEEE Control Systems Magazine, February, 30-43.

De Hoyos R.E. \& V. Sarafidis (2006), "Testing for cross-sectional dependence in panel-data models", The Stata Journal, 6, Number 4, 482-496.

Frees, E.W. (1995), “Assessing cross-sectional correlation in panel data”, Journal of Econometrics 69:393, 414-496.

Frees, E.W. (2004), Longitudinal and Panel Data: Analysis and Applications in the Social Sciences, Cambridge: Cambridge University Press.

Friedman, M. (1937), "The use of ranks to avoid the assumption of normality implicit in the analysis of variance", Journal of the American Statistical Association, 32: 675-701.

Friedman, M. (1968), “The role of monetary policy”, American Economic Review, 58, 1-17.

Gil-Alana, Luis (2001), "The Persistence of Unemployment in the USA and Europe in Terms of Fractionally ARIMA Models", International Review of Applied Economics, Vol. 16, No:4, 465-477.

Gil-Alana, Luis (2002), "ModelingThePersistence of Unemployment in Canada", International Review of Applied Economics, Vol. 16, No: 4, 465-477.

Gomes, F.R. \& C.G. Silva (2009), "Hysteresis Versus NAIRU and Convergence Versus Divergence: The Behavior of Regional Unemployment Rates in Brazil", The Quarterly Review of Economics and Finance, 49, 308-322.

Gordon, Robert J. (2009), “The History of the Phillips Curve: Consensus and Bifurcation”, NBER Working Paper, March 7, 2009.

Gren, Francis (1992), "Unemployment Hysteresis and The Worker Discipline Effect”, European Journal of Political Economy, Vol.8, Issue: 4, 543-556.

Güloğlu, B. \& S. İspir (2001), "Doğal İşsizlik Oranı mı? İşsizlik Histerisi mi? Türkiye için Sektörel Panel Birim Kök Sınaması Analizi”, Ege Akademik Bakış Dergisi, No:11(2), 205-215.

Jones, D.R. \& D.N. Manning (1992), "Long Term Unemployment, Hysteresis and the Unemployment-Vacancy Relationship: A Regional Analysis", Regional Studies, Vol. 26, No:1, 17-29.

Knut, Roed (1999), "A Note on TheMacroeconomic Modelling of Unemployment Hysteresis", Applied Economics Letters, Vol. 6, 255-258.

Koçyiğit, Ali \& T. Bayat \& A. Tüfekçi (2011), “Türkiye'de İşsizlik Histerisi ve Star Modelleri Uygulaması”, Marmara Üniversitesi İ.I..B.F. Dergisi, Cilt: XXXI, Say1: II, 45-60.

Koustas, Zisimos \& William Veloce (1996), "Unemployment Hysteresis in Canada: an Approach Based on Long-Memory Time Series Models", Applied Economics, Vol. 28, 823-831.

Küçükkale, Y. (2001), “Doğal İşsizlik Oranındaki Keynesyen İsteri Üzerine Klasik Bir İnceleme: Kalman Filtre Tahmin Tekniği ile Türkiye Örneği 1950-1995”, V. Ulusal Ekonometri ve İstatistik Sempozyumu, Adana, <http://idari.cu.edu.tr/sempozyum/bil40.htm>, 01.04.2012. 
Layard, R. \& S. Nickell \& R. Jackman (1991), Unemployment, Macroeconomic Performance and the Labour Market, Oxford University Press, Oxford.

Leon-Ledesma, M.A. (2002), "Unemployment Hysteresis in the US and EU: A Panel Data Approach", Bulletin of Economic Research, 54(2), 94-102.

Levin, A. \& C.F. Lin \& C.S.J. Chu (2002), "Unit root tests in panel data: Asymptotic and finitesample properties", Journal of Econometrics, 108: 1-24.

Lipsey, R.G. (1960), "The Relation Between Unemployment and the Rate of Change of Money Wage Rates: A Further Analysis," Economica, Vol.: 27, February, No:105, 1-31.

Lordoğlu, K. \& N. Özkaplan (2005), Çalışma İktisadı, Der Yayınları, İstanbul.

Onur, Sara (2011), Türkiye Ekonomisinde İssizlik Histerisi (1992-2009), Sosyal Bilimler Metinleri 04/2011, <http://sosyalbe.nku.edu.tr/>, 11.09.2012.

Pazarlığlu, M.V. \& İ. Çevik (2007a), "Ratchet Model Uygulaması: Türkiye Örneği”, VII. Ulusal Ekonometri ve Ístatistik Sempozyumu, İstanbul.

Pazarlığlu, M.V. \& E.İ. Çevik (2007b), "Ratchet Model: 1939-2005 Dönemi Türkiye Uygulaması", Trakya Üniversitesi Sosyal Bilimler Dergisi, Cilt: 9, Say1: 1 Haziran, 17-34.

Pesaran, M.H. (2004), “General diagnostic tests for cross section dependence in panels”, University of Cambridge, Faculty of Economics, Cambridge Working Papers in Economics, No. 0435.

Phelps, E.S. (1968), “Money-Wage Dynamics and Labor-Market Equilibrium”, Journal of Political Economy, Vol. 76, 678-711.

Phelps, E.S. (1972), Inflation Policy and Unemployment Theory: The Cost-Benefit Approach to Monetary Planning, Macmillan.

Phelps, E.S. (1999), "Behind the Structural Boom, the Role of Assets Valuations", American Economic Review, Vol. 89, 167-188.

Phillips, A.W. (1958), "The Relation between Unemployment and the Rate of Change of Money Wage Rates in the United Kingdom, 1861-1957”, Economica, Vol. 25, No: 100, 283299.

Roed, K. (1996), “Unemployment hysteresis . macroevidence from 16 OECD Countries”, Empirical Economics, 21, 589-600.

Samuelson, Paul A. \& Robert M. Solow (1960), “Analytical Aspects of Anti-Inflation Policy," American Economic Review Papers and Proceedings, Vol: 50: May, No: 2, 177-194.

Sevüktekin, Mustafa (1995), "Model Kararlılığının Belirlenmesi için bir Test: CUSUM ve CUSUMSQ Testi," Dokuz Eylül Üniversitesi İktisadi ve İdari Bilimler Fakültesi Dergisi, 10, II, 313-21.

Smyth, David J. \& Joshy Z. Easaw (2001), "Unemployment Hysteresis and the NAIRU: a Ratchet Model”, Applied Economics Letters, Vol. 8, 359-362.

Song, F.M. \& Y. Wu (1997), "Hysteresis in Unemployment: Evidencefrom 48 States", Economic Inquiry, Vol. 35, 235-244. 
İbrahim TOKATLIOĞLU \& Fahriye ÖZTÜRK \& Hakan Naim ARDOR

Stanley, T.D. (2002), When all are NAIRU: Hysteresis and Behavioural Intertia, Applied Economics Letter, Vol. 9, 753-757.

Tunal1, Halil (2010), “The Analysis of Unemployment in Turkey: Some Empirical Evidence Using Co-integration Test", European Journal of Social Sciences, Volume 18, Number 1, 1838.

Yılancı, V. (2009), “Yapısal Kırılmalar Altında Türkiye için İşsizlik Histerisinin Sınanması”, Doğuş Üniversitesi Dergisi, No:10(2), 324-335. 